Gut, 1987, 28, 1669-1672

\title{
Crohn's disease with respiratory tract involvement
}

\author{
M LEMANN, B MESSING, F D'AGAY, AND R MODIGLIANI \\ From the Service de gastroentérologie, Hôpital Saint-Lazare, Paris, France, and Service d'anatomopathologique \\ Hôpital Saint-Louis, Paris, France
}

SUMMARY Symptomatic respiratory tract involvement with granulomatous bronchial lesions has not yet been described in Crohn's disease. We report two patients with colonic Crohn's disease and severe respiratory symptoms (dyspnoea associated in one of the patients with voicelessness); erythema, aphthoid and superficial ulcerations were found in the colon and whitish granulations in the bronchi at endoscopy. Non-caseating tuberculoid granulomas were found in the colonic mucosa of both patients, as well as in the bronchial mucosa of one of them; in the second a diffuse inflammatory infiltrate including epithelioid cells was found underneath an erosion of bronchial epithelium. Both patients improved on oral prednisone. These two patients probably had bronchial involvement by Crohn's disease.

Some recent papers have shown a high incidence of latent pulmonary abnormalities in Crohn's disease (CD), as assessed by respiratory function tests ${ }^{1-6}$ or bronchoalveolar lavage. ${ }^{n-x}$ In contrast, the observation of symptomatic respiratory tract involvement in $\mathrm{CD}$ seems very rare. ${ }^{4-15} \mathrm{We}$ report two cases of Crohn's colitis associated with laryngeal and/or bronchial involvement. To our knowledge, the bronchial lesions in our patients have not been described previously.

\section{Case 1}

A previously healthy 24 year old French woman first presented in August 1985 because of diarrhoea and fever. Two months earlier, during the third trimester of her second pregnancy, she began to complain of diarrhoea. She received loperamide and nonabsorbable antibiotics, with some improvement. Two weeks after delivery, diarrhoea recurred, associated with abdominal pain, fever, weight loss and increasing weakness.

On admission the temperature was $39 \cdot 5^{\circ} \mathrm{C}$, the pulse 126 and the blood pressure $90 / 60 \mathrm{~mm} \mathrm{Hg}$.

\footnotetext{
Address for correspondence: Dr R Modigliani. Service de gastroentérologie. Hôpital Saint-Lazare 107, rue du Faubourg Saint-Denis, 75475 Paris Cédex 10. France.

Received for publication 8 May 1987
}

Physical examination was negative except for mild abdominal tenderness. Laboratory studies showed the following abnormalities: haematocrit $31 \%$; white cell count 19000 with $84 \%$ neutrophils; sedimentation rate $72 \mathrm{~mm} / \mathrm{h}$; potassium $2.6 \mathrm{mmol} / \mathrm{l}$; creatinine $170 \mu \mathrm{mol} / \mathrm{l}$; and albumin $2.9 \mathrm{~g} / \mathrm{dl} . X$-ray films of the abdomen and of the chest were normal. Stool cultures and parasitic research were negative. Colonoscopy revealed abnormalities confined to the ascending and sigmoid colon with hyperhemic mucosa, aphtoid, and superficial ulcerations. Multiple mucosal biopsy specimens revealed nonnecrotising granulomas. Barium small bowel radiographs were normal. The diagnosis of $C D$ was considered, and the treatment consisted of parenteral nutrition, antibiotics, and sulphasalazine 3 g daily.

After initial improvement, the temperature rose to $39^{\circ} \mathrm{C}$ on the 10 th hospital day and the patient became voiceless; she experienced dysphagia, cough and mild dyspnoea. Simultaneously, erythema nodosum appeared on the legs and forearms. There was a mild but transient exacerbation of the digestive symptoms. An upper airway examination revealed marked oedema of the nasopharynx, epiglottis, arytenoids and true vocal cords. There was no cervical lymphadenopathy; lung examination was normal. Chest radiograph remained normal. 
Bronchoscopy disclosed erythema and numerous small whitish granulations of trachea and main stem bronchi. Biopsy showed a chorionic mononuclear infiltrate with a few tuberculoid granulomas made of epithelioid cells (Figure). The aspirate was negative for acid fast bacilli on both smear and culture. Liver function tests and serum calcium were normal. The serum creatinine was $82 \mu \mathrm{mol} / \mathrm{l}$. An angiotensin converting enzyme was $37 \mu \mathrm{mol} / \mathrm{min} / \mathrm{l}$ (normal range 65-135). Serologic test for Yersinia enterolitica and pseudotuberculosis infection, cytomegalovirus infection, histoplasmosis, brucellosis, and syphilis were negative.

The patient was treated with oral prednisone $40 \mathrm{mg}$ daily. She responded dramatically, with complete relief of respiratory symptoms within a few days. One month later she was symptom free. Bronchoscopy showed a nearly normal appearance of the mucosa with slight, non-specific infiltrate on biopsy. Colonoscopy two months later showed moderate erythema without ulceration. Steroids were then tapered off. She has now been off steroids and asymptomatic for 12 months.

\section{Case 2}

A 17 year old French woman was first seen in 1981 for evaluation of erythema nodosum. There was no history of digestive disease or pulmonary symptoms and the aetiology of this skin lesion remained obscure despite multiple investigations, including a normal colonoscopy and ileoscopy. During the next two years she developed four attacks of erythema nodosum and she was referred in January 1983 because of mild hyperamylasemia noticed at routine laboratory test. An endoscopic retrograde pancreatography showed slightly dilated and irregular ducts.

In April 1983, she was readmitted for diarrhoea of two months duration (four to five liquid stools with blood daily), recurrence of erythema nodosum, and acute dyspnoea. She was treated with a presumptive diagnosis of severe asthma and received high dose intravenous steroids. Radiographs of the chest was normal. Bronchoscopy showed a diffusely erythematous mucosa with numerous small whitish granulations. Bronchial biopsy samples showed an erosion of the bronchial epithelium underlined by an infiltrate, predominantly of polymorphs; epithelioid like macrophages were also seen, without tendency to form aggregates. At colonoscopy small ulcerations of the right colon and a thickened and erythematous mucosa in the transverse and left colon were found. The rectum was normal. Several biopsy samples showed superficial ulcerations and tuberculoid granulomas with epithelioid and giant cells. Small bowel barium radiographs were normal. Ocular

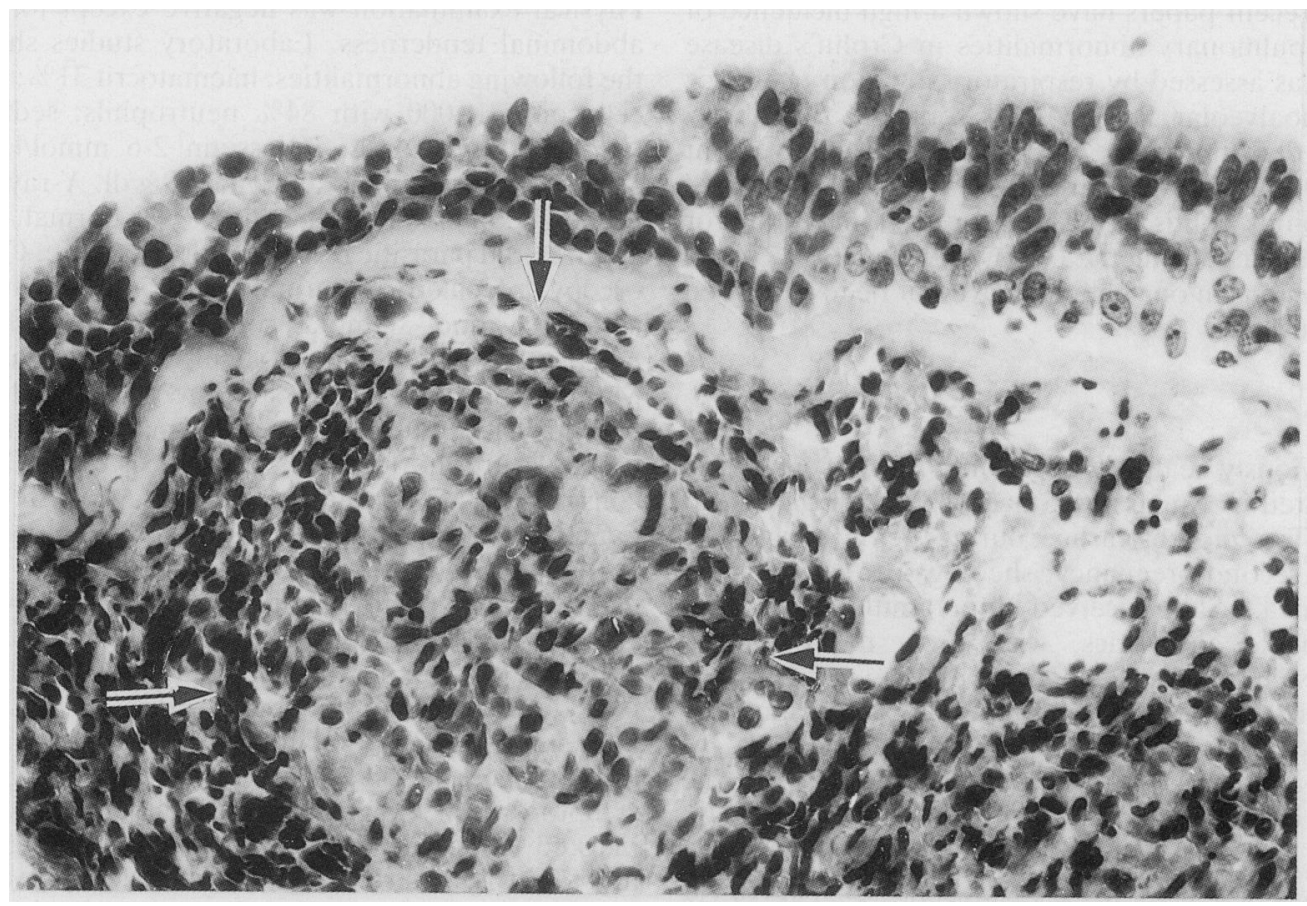

Figure Bronchial biopsy from patient 1 showing chorionic mononuclear infiltrate with tuberculoid granuloma (arrows) made of epithelioid cells ( $H$ and $E$ ). 
examination showed episcleritis. Digestive and extradigestive symptoms improved on prednisone therapy. During the following two years, the patient suffered from further attacks of colitis, erythema nodosum and episcleritis, but had no respiratory symptoms. On each occasion, an improvement was achieved on oral prednisone.

\section{Discussion}

Our two patients had simultaneous occurrence of segmental colitis and laryngeal and/or bronchial involvement. At endoscopy, erythema, aphtoid and superficial ulcerations were seen in the colon and whitish granulations in the bronchi. Non-caseating tuberculoid granulomas were found in the colonic biopsy specimens in both cases as well as in the bronchial mucosa of the first patient. In the second case the infiltrate of the bronchial lamina propria included epithelioid like macrophages but without follicular or nodular pattern. Infectious and parasitic causes of granulomatous colitis such as tuberculosis, yersiniosis, histoplasmosis, and bilharziosis can be reasonably ruled out in our patients.

Sarcoidosis and Crohn's disease have several common features: unknown aetiology, presence of non-caseating granulomas as one of the histological hallmarks, occurrence of erythema nodosum, episcleritis and uveitis, responsiveness to steroids. Yet the clinical pictures of these two diseases are usually easy to differentiate, because of the topography of the lesions: while both diseases may be disseminated, sarcoidosis involves mainly mediastinal lymph nodes and lungs while $\mathrm{CD}$ is essentially a digestive disease. The diagnosis of CD seems much more likely than that of sarcoidosis in our two patients: they had no evidence of disseminated sarcoidosis or radiological indication of mediastinal lymph nodes or lung disease. Intestinal sarcoidosis is exceptional and always occurs in a setting of otherwise obvious sarcoidosis. Only three cases of diffuse small bowel infiltrate by non-caseating granuloma have been reported in disseminated sarcoidosis. ${ }^{16-18}$ To our knowledge, 10 cases have been reported as colonic sarcoidosis: five had widespread sarcoidosis with either ${ }^{19}{ }^{20}$ purely histological large bowel involvement (tuberculoid granulomas on rectal biopsy) and no related clinical or endoscopic abnormality $(n=2)$, or $^{21-23}$ macroscopic colonic disease with clinical symptoms $(n=3)$. Only one case of colonic stenosis is mentioned in a series of 160 cases of sarcoidosis. ${ }^{24}$ Finally four cases were published as colonic sarcoidosis before the individualisation of colonic Crohn's disease $^{25}$ and would undoubtedly be labelled as such today, ${ }^{26-29}$

Respiratory abnormalities have been reported in a few patients with CD: (1) three cases ${ }^{910}$ of $C D$ were found to be associated with upper airway obstruction and laryngeal involvement (extensive oedema of the epiglottis, aryepiglottic folds, false cords and arythenoids); tuberculoid granulomas were found at laryngeal biopsy in one of them; ${ }^{10}$ bronchial examination is not mentioned in these cases; all improved on steroids. (2) Unexplained chronic bronchial suppuration with bronchiectasis has been described in association with ulcerative colitis ${ }^{112}$ and in one case of probable CD. ${ }^{11}$ (3) A pulmonary infiltrate with a non-caseating tuberculoid granuloma has been published in three CD patients. ${ }^{13-15}$ (4) Finally, subclinical lung abnormalities have been observed in $\mathrm{CD}$, such as abnormal pulmonary function tests, ${ }^{1-6}$ decreased carbon monoxide diffusion ${ }^{156}$ and more recently a high incidence of latent lymphocyte alveolitis as assessed by bronchoalveolar lavage..$^{6-8}$ Interestingly, this $\mathrm{CD}$ alveolar lymphocytosis results, as in sarcoidosis, from an expansion of the T4 lymphocyte subset; ${ }^{68}$ whether this finding reflects some underlying pathophysiological mechanism common to both diseases remains to be seen. To the best of our knowledge, the bronchial abnormalities described in our patients have not been reported as yet.

\section{References}

1 Johnson NM, Mee AS, Jewell DP, Clarke SW. Pulmonary function in inflammatory bowel disease. Digestion 1978; 18: 416-8.

2 Eade OE, Smith CL, Alexander JR, Whorwell PJ. Pulmonary function in patients with inflammatory bowel disease. Am J Gastroenterol 1980; 73: 154-6.

3 Pasquis P, Baptiste P, Denis P, Colin R, Le Francois R. Fonction respiratoire au cours de la maladie de Crohn. Rev Fr Mal Resp 1980; 8: 49-50.

4 Pasquis P, Colin R, Denis P, Baptiste P, Galmiche JP, Hecketsweiler P. Transient pulmonary impairment during attacks of Crohn's disease. Respiration 1981; 41: 56-9.

5 Heatley RV, Thomas P, Prokipchuk EJ, Gauldie J, Sieniewicz DJ, Bienenstock J. Pulmonary function abnormalities in patients with inflammatory bowel disease. $Q J$ Med 1982; 51: 241-50.

6 Bonniere $\mathrm{P}$, Wallaert B, Cortot A, et al . Latent pulmonary involvement in Crohn's disease: biological, functional, bronchoalveolar lavage and scintigraphic studies. Gut 1986; 27: 919-25.

7 Wallaert B, Colombel JF, Tonnel AB, et al. Evidence of lymphocyte alveolitis in Crohn's disease. Chest 1985; 87: 363-6.

8 Smiejan JM, Cosnes J, Chollet-Martin S, et al. Sarcoidlike lymphocytosis of the lower respiratory tract in patients with active Crohn's disease. Ann Intern Med 1986; 104: 17-21.

9 Croft CB, Wilkinson AR. Ulceration of the mouth, pharynx and larynx in Crohn's disease of the intestine. Br J Surg 1972; 59: 248-52. 
10 Kelly JH, Montgomery WW, Goodman ML, Mulvaney TJ. Upper airway obstruction associated with regional enteritis. Ann Otol 1979; 88: 95-9.

11 Kraft SC, Earle RH, Roesler M, Esterly JR. Unexplained bronchopulmonary disease with inflammatory bowel disease. Arch Intern Med 1976; 136: 454-9.

12 Butland RJA, Cole P, Citron KM, Turner-Warwick M. Chronic bronchial suppuration and inflammatory bowel disease. $Q J$ Med 1981; 50: 63-75.

13 Chapin LF, Scudamore HH, Baggenstoss AH, Bargen JA. Regional enteritis. Associated visceral changes. Gastroenterology 1965; 30: 404-15.

14 Henrion F, Bretagne MC, Neimann L, Flechon PE, Canton P, Hoeffel JC. Association exceptionnelle de lésions pulmonaires, cutanées, et d'une iléite terminale chez un enfant de 11 ans. J Radiol 1982; 63: 123-6.

15 Shah SM, Texter EC, White HJ. Inflammatory bowel disease associated with granulomatous lung disease: report of a case with endoscopic findings. Gastrointest Endosc 1976; 23: 98-9.

16 Miyamoto C, Nomura S, Kudo E, Hamamoto Y. An autopsy case of sarcoidosis in the intestinal canal. Bull Osaka Med School 1972; 18: 48-55.

17 Clague RB. Sarcoidosis or Crohn's disease? Br Med J 1972; 3: 804.

18 Sprague R, Harper P, Mac Clain S, Trainer T, Beeken W. Disseminated gastrointestinal sarcoidosis. Case record and review of the literature. Gastroenterology 1984; 87: 421-5.
19 Gould SR, Handley AJ, Bernardo DE. Rectal and gastric involvement in a case of sarcoidosis. Gut 1973; 14: $971-3$.

20 Debray C, Darnaud C, Voisin R, Martin E, Moreau G. Les localisations sur le tube digestif de la maladie de Besnier-Boeck-Schaumann. Arch Fr Mal App Dig 1967; 56: 253-73.

21 Aaronson HG, Meir JH, Ulin AW. A case of sarcoidosis of the colon. J Albert Einstein Med Center 1957; 6: 14-16.

22 Kohn NN. Sarcoidosis of the colon. J Med Soc NJ 1980; 77: $517-8$.

23 Konda J, Ruth M, Sassaris M, Hunter FM. Sarcoidosis of the stomach and rectum. Am J Gastroenterol 1980; 73: 516-8.

24 Israel HL, Sone M. Sarcoidosis. Clinical observations in one hundred sixty cases. Arch Intern Med 1958; 102: 766-76.

25 Lockhart-Mummery HE, Morson BC. Crohn's disease (regional enteritis) of the large intestine. Gut 1964; 5: 493-509.

26 Raven RW. The surgical manifestations of sarcoidosis. Ann $R$ Coll Surg 1949; 5: 3-28.

27 MacFarlane DA. Intestinal sarcoidosis. Br J Surg 1955; 42: $639-42$.

28 Gourevitch A, Cunningham IJ. Sarcoidosis of the sigmoid colon. Postgrad Med J 1959; 35: 689-91.

29 Barre Y, Guibout P, Couffin JP, Caulet T, Diebold J. Sarcoidose gastrique avec localisation rectale latente. Arch Fr Mal App Dig 1966; 55: 403-10. 